\title{
n-3 Fatty acid intake from marine food products among Quebecers: comparison to worldwide recommendations
}

\author{
Michel Lucas ${ }^{1,2, *}$, Geneviève Asselin ${ }^{1}$, Mélanie Plourde ${ }^{3}$, Stephen C Cunnane ${ }^{3}$, \\ Éric Dewailly ${ }^{2,4}$ and Sylvie Dodin ${ }^{1,5}$ \\ 'Lucie and André Chagnon Chair for the Teaching of an Integrated Approach in Prevention, Laval University, \\ Saint-François d'Assise Hospital (CHUQ), Québec, QC, Canada: ${ }^{2}$ Axe Santé des populations et environnement, \\ Centre Hospitalier de I'Université Laval (CHUL-CHUQ), 2875 Laurier Blvd, Delta Building \#2 - Office 600, \\ Québec, Québec (QC) G1V 2M2, Canada: ${ }^{3}$ Research Centre on Aging, Sherbrooke University, Sherbrooke, \\ QC, Canada: ${ }^{4}$ Department of Social and Preventive Medicine, Laval University, Sainte-Foy, QC, Canada: \\ ${ }^{5}$ Department of Obstetrics and Gynaecology, Laval University, Québec, QC, Canada
}

Submitted 25 July 2008: Accepted 31 March 2009: First published online 12 May 2009

\begin{abstract}
Objective: To quantify marine food product consumption and EPA + DHA intake among Quebecers, and to compare the results with the most recent recommendations.

Design: Data were obtained from a representative cross-sectional telephone survey (June 2006). Intakes of marine food product species and EPA + DHA were estimated from a validated FFQ on the consumption of marine food products during the previous month. Prevalence of fish oil consumption in the last 6 months was also assessed.

Setting: Province of Quebec (Canada).

Subjects: A representative sample ( $n$ 1001) of adults in the province of Quebec. Of these, eight were excluded from the present analysis ( $n$ 993).

Results: Mean and median EPA + DHA intakes for all participants were estimated to be $291 \mathrm{mg} / \mathrm{d}$ (SEM 11) and $207 \mathrm{mg} / \mathrm{d}$, respectively. 85.0\% (95\% CI 82.7, 87.3) of Quebecers had an EPA + DHA intake lower than $500 \mathrm{mg} / \mathrm{d}$, which is the amount internationally recommended for the prevention of CVD. Mean and median DHA intakes among women of childbearing age ( $n$ 128, 18-34 years) were estimated to be $169 \mathrm{mg} / \mathrm{d}$ (SEM 17) and $126 \mathrm{mg} / \mathrm{d}$, respectively. Of these women, $27 \cdot 7 \%$ had a daily intake $>200 \mathrm{mg}$ DHA and $15.9 \%$ had an intake $>300 \mathrm{mg}$ DHA. We noted that $13 \%$ of Quebecers take $\geq 1$ capsule of fish oil/d.

Conclusions: Consumption of marine food products and EPA + DHA among Quebecers clearly appears to be lower than international recommendations. Since $\mathrm{EPA}+\mathrm{DHA}$ confer health benefits and may reduce health costs, strategies to increase their consumption should be implemented to improve public health in Quebec.
\end{abstract}

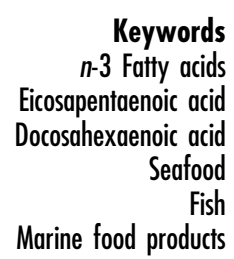

Keywords

icosapentaenoic acid noic acid

Fish

Marine food products
Decreasing intake of $n-3$ fatty acids and increasing intake of $n$ - 6 fatty acids are widely considered to be contributing to the rising incidence of many chronic, degenerative diseases $^{(1)}$. However, it has been suggested that $n$ - 3 from fish and seafood might be the more important factor in total $n-3 /$ total $n-6$ ratios, and that the utilisation of ratios is mathematically problematic ${ }^{(2)}$. Fish and seafood contain two $n$-3 long-chain (LC) PUFA - EPA and DHA - both of which appear to be beneficial for the prevention or treatment of $\mathrm{CVD}^{(3)}$ and inflammatory disorders, such as rheumatoid arthritis ${ }^{(4)}$. Although humans are technically capable of endogenously synthesising EPA and DHA from the $n-3$ precursor in plants ( $\alpha$-linolenic acid; $\alpha$-LNA), this conversion is a very inefficient way of increasing
DHA in tissues ${ }^{(5)}$. Therefore, in general, EPA and DHA concentrations in blood reflect habitual dietary EPA and DHA intake ${ }^{(6)}$.

In CVD prevention, it has been proposed ${ }^{(7)}$ that interventions should initially concentrate on lifestyle factors linked to CVD risk factors (hypertension, hypercholesterolaemia or diabetes) ${ }^{(8)}$ or nutritional factors for which there is evidence of a protective effect, such as the consumption of fish, fish oil or marine food products ${ }^{(3)}$. Several organisations recommend $n$ - 3 LC PUFA to reduce CVD risk, especially sudden death and death from CHD in adults ${ }^{(3,9)}$. n-3 LC PUFA may also have beneficial outcomes on mental health ${ }^{(10)}$. A recent evidence-based review of international recommendations for LC $n-3$ fatty 
Table 1 International recommendations for EPA and DHA

\begin{tabular}{|c|c|}
\hline Source (date) and references & $\begin{array}{l}\text { Recommendations } \\
\text { EPA and DHA }(\mathrm{mg} / \mathrm{d})\end{array}$ \\
\hline $\begin{array}{l}\text { UK Committee on Medical } \\
\text { Aspects of Food Policy } \\
(1994)^{(24)}\end{array}$ & $100-200$ \\
\hline FNB-IOM, USA (2002) & $130-270^{*}$ \\
\hline Eurodiet $(2000)^{(26)}$ & 200 \\
\hline $\begin{array}{l}\text { Health Council of the } \\
\text { Netherlands }(2001)^{(27)}\end{array}$ & 200 \\
\hline PeriLip ${ }^{(18)}$ & $\begin{array}{l}\text { Pregnancy and lactation }>200 \\
\text { DHA }\end{array}$ \\
\hline ANC (France) $(2001)^{(28)}$ & $450(\mathrm{DHA}, 110-120)$ \\
\hline NHMRC of Australia (2005) $)^{(29)}$ & $430+$ (women), $610+$ (men) \\
\hline WHO/FAO (2003) ${ }^{(30)}$ & $400-1000$ (1-2 fish meals/week) \\
\hline $\begin{array}{l}\text { UK Scientific Advisory } \\
\text { Committee on Nutrition } \\
(2004)^{(31)}\end{array}$ & $\begin{array}{l}\text { Minimum two fish meals/week } \\
\text { (one fatty fish) } \approx 450\end{array}$ \\
\hline ISSFAL Workshop (2004) ${ }^{(32)}$ & $\geq 500$ \\
\hline ADA/DC (2007) $)^{(33)}$ & $\begin{array}{l}\text { Two fish meals/week (fatty fish), } \\
8 \mathrm{oz} \text { cooked fish } \approx 500\end{array}$ \\
\hline $\begin{array}{l}\text { AHA/AHA Nutrition Committee } \\
(2002,2006)^{(3,34)}\end{array}$ & $\begin{array}{l}\text { Two fish meals/week (fatty fish) } \\
\quad \approx 430-570\end{array}$ \\
\hline $\begin{array}{l}\text { ISSFAL Expert Workshop } \\
(1999)^{(35)}\end{array}$ & $\begin{array}{l}650 \\
\text { Pregnancy and lactation }>300 \\
\text { DHA }\end{array}$ \\
\hline NATO Workshop (1989) ${ }^{(36)}$ & 800 \\
\hline $\begin{array}{l}\text { British Nutrition Foundation } \\
(1992)^{(37)}\end{array}$ & $1100 t$ \\
\hline $\operatorname{AHA}(2002)^{(3)}$ & 1000 (2nd CHD prevention) \\
\hline $\begin{array}{l}\text { European Society of } \\
\text { Cardiology }(2003)^{(38)}\end{array}$ & 1000 (2nd CHD prevention) \\
\hline
\end{tabular}

$\alpha$-LNA, alpha-linolenic acid (18:3n-3); ADA, American Dietetic Association; AHA, American Heart Association; ANC, Apports nutritionnels conseillés: DC, Dietitians of Canada; DHA (22: 6n-3); EPA (20:5n-3); FNB-IOM, Food and Nutrition Board of the Institute of Medicine of the National Academies of Science; ISSFAL, International Society for the Study of Fatty Acids and Lipids; NATO, North Atlantic Treaty Organization; NHMRC, National Health and Medical Research Council; PeriLip, Perinatal Lipid Intake Working Group.

*EPA and DHA can contribute up to $10 \%$ of total $n-3$ intake and, therefore, up to this percentage can contribute toward the adequate intake of $\alpha$-LNA $(18: 3 n-3)(1 \cdot 3-2 \cdot 7 \mathrm{~g} / \mathrm{d})$.

tn-3 long-chain PUFA: EPA, DHA, DPA (docosapentaenoic acid, 22:5n-3).

acids indicates that an intake of $500 \mathrm{mg} / \mathrm{d}$ of EPA and DHA reduces CVD risk ${ }^{(11)}$. This daily EPA and DHA intake has been suggested by several health agencies worldwide (Table 1).

The intake of $n-3$ LC PUFA during pregnancy and lactation is also associated with beneficial effects for mothers and the mental development of their children ${ }^{(10,12)}$. Since the fetus is unable to synthesise sufficient DHA for the development of its nervous system, it depends on the mother for $\mathrm{DHA}^{(13)}$. Preformed DHA is preferred for infants and is obtained prenatally via the placenta, postnatally from breast milk, fat stores, supplemented formula and, later, from foods ${ }^{(14,15)}$. Breast-feeding is the preferred method of infant feeding ${ }^{(16)}$. The DHA content of breast milk is strongly positively associated with the frequency of fish intake and $n-3$ LC PUFA intake ${ }^{(12,16)}$. However, supplementation of breast-feeding mothers with the DHA precursor $\alpha$-LNA $(10.7 \mathrm{~g} / \mathrm{d})$ from flaxseed oil does not increase DHA in breast milk ${ }^{(17)}$. Recently, a European collaborative group indicated that providing
EPA and DHA at $1-2 \cdot 7 \mathrm{~g} / \mathrm{d}$ to pregnant and lactating women had no significant adverse effects ${ }^{(18)}$. To assure sufficient DHA for fetal and maternal tissue DHA accretion, the recommended daily intake of DHA during pregnancy and lactation has been set at $200 \mathrm{mg}$ by the Perinatal Lipid Intake Working Group (PeriLip) ${ }^{(18)}$, and $300 \mathrm{mg}$ by the International Society for the Study of Fatty Acids and Lipids (ISSFAL) ${ }^{(19)}$.

In 1990, the consumption of fish and n-3 LC PUFA did not represent a significant part of the diet of Quebecers $^{(20,21)}$. Between 1990 and 1992, Santé-Québec, an organisation of the Québec Ministry of Health and Social Services, conducted a series of health surveys among southern Quebecers, James Bay Cree (Northwestern Quebec) and Inuit of Nunavik (Northern Quebec). Data from $24 \mathrm{~h}$ dietary recalls revealed that on the day before each survey, mean daily consumption of fish was $13 \mathrm{~g}$ for Southern Quebecers, $60 \mathrm{~g}$ for James Bay Cree, and $131 \mathrm{~g}$ for the Inuit of Nunavik. The daily fish intake of the Cree and Inuit populations provided $\sim 700-900$ and $2115 \mathrm{mg}$ of $\mathrm{EPA}+\mathrm{DHA}$, respectively ${ }^{(21)}$. However, fish intake among Southern Quebecers provided $<200 \mathrm{mg} / \mathrm{d}$ of EPA + DHA, a level also observed in the $\mathrm{USA}^{(22)}$. In parallel, a natural health product that is becoming more popular in the Canadian population is fish oil or supplements containing EPA and DHA. Indeed, according to the 2000-2001 Canadian Community Health Survey (CCHS) results, the proportion of Canadians who took fish oil was $9 \cdot 4 \%^{(23)}$.

Much scientific and lay publicity concerning the benefits of $n-3$ LC PUFA intake has circulated worldwide since Santé-Québec's health surveys in the $1990 s^{(20,21)}$. Although EPA and DHA have recently gained in popularity, little is known about their actual intake by Quebecers. From a public health standpoint, it was therefore important to know the actual EPA + DHA intake of the Quebec population. To our knowledge, no other recently published studies have attempted to quantify fish consumption and dietary EPA + DHA intake among Quebecers. The primary objective of the present study was, therefore, to analyse marine food product consumption and EPA + DHA intake among a representative sample of adults from the province of Quebec, and to compare these values with the most recent recommendations (Table 1 ).

\section{Subjects and methods}

\section{Study design and participants}

Data were obtained from a representative cross-sectional telephone survey ( $n$ 1001) by random digital dialling for the selection of one adult ( $>18$ years) per household. During the telephone survey, participants were asked to complete a validated FFQ about marine food products ${ }^{(6)}$. Telephone interviews were conducted by trained interviewers from the largest independent market research 
firm in Canada - Léger Marketing (Montréal). Sampler software (ASDE Survey Sampler Inc., Gatineau, QC, Canada) selected the random sampling population. The margin of error for the $95 \%$ CI of this survey was $\pm 3.4 \%$. The response rate was $56.9 \%$. Among the 1001 participants interviewed, eight gave aberrant answers to questions on marine food product consumption (e.g. twenty meals of $226 \mathrm{~g}$ or $8 \mathrm{oz} /$ week) and were, therefore, excluded from the present analysis ( $n$ 993). Gender, age, occupation, level of education, income and region were available for each respondent. Furthermore, a weight was established for each respondent according to the latest data from Statistics Canada regarding region, maternal language, gender and age. Therefore, the data presented in the present paper were obtained from weighted data and represented the adult population of Quebec as a whole.

\section{Assessment of marine food product intake}

Data on the consumption of marine food products were generated by completion of a validated FFQ, which evaluated marine food product intake within the last month. Validation and more details of the FFQ have been given elsewhere $^{(6)}$. Briefly, the FFQ was validated by measuring the relationship between baseline EPA + DHA intake assessed by this FFQ and EPA + DHA concentration in red blood cells (RBC) among a sample of middleaged women $(n 65)$ participating in a randomised clinical trial. Analyses indicated that baseline EPA + DHA intake, measured by our FFQ, correlated reasonably well (Spearman's $r=0 \cdot 42, P=0 \cdot 0005$ ) with $\mathrm{EPA}+\mathrm{DHA}$ concentration in RBC at baseline. The FFQ had two principal questions. The first question referred to the portion size of fish consumed: 'In general, what is the portion size that corresponds best to your habitual consumption when you eat fish?' The second question of the FFQ was aimed at knowing the frequency of marine food products consumed: 'Based on your food consumption of the last month, how many times did you consume the following marine food products?' The questionnaire included seven groups of marine food products: (i) oily fish (fresh or canned salmon, herring, mackerel, sardines); (ii) canned tuna; (iii) trout or halibut; (iv) white fish (sole, rockfish, haddock, cod, etc.); (v) molluscs (mussels, oysters, clams, scallops); (vi) crustaceans (shrimps, crabs, lobsters, etc.); (vii) imitation crab. Based on the 2005 Canadian Nutrient File of Health Canada ${ }^{(39)}$, each of these groups of marine food products was assigned an amount of EPA and DHA. A question concerning fish oil consumption was also added to the FFQ: 'Over the last 6 months, what was your fish oil supplement consumption (capsules containing marine omega-3 fatty acids)?'

\section{Statistical analysis}

The statistical distribution of marine food product and $\mathrm{EPA}+\mathrm{DHA}$ intakes was found to be skewed. Therefore, log transformation was undertaken to compare marine food product and EPA + DHA intakes relative to socioeconomic characteristics. Arithmetic means were also calculated to facilitate comparisons with other studies. Student's $t$ test was only used to compare EPA + DHA intake between genders. An ANOVA test with Bonferroni correction for multiple comparisons compared EPA + DHA intake according to other participant characteristics (age, occupation, level of education and income). Geometric mean values ( $95 \% \mathrm{CI}$ ) were presented for comparisons according to participants' characteristics. The $\chi^{2}$ test was performed to compare the proportion of Quebecers who had an intake lower than the international recommendation for CVD protection $(500 \mathrm{mg}$ $\mathrm{EPA}+\mathrm{DHA} / \mathrm{d}$ ), according to gender. Since DHA intake is a key nutrient during pregnancy and lactating periods, we extracted data on this parameter among women of childbearing age ( $n$ 128, 18-34 years). DHA intake of these women was compared to the daily intake recommended during pregnancy and lactation by PeriLip $(>200 \mathrm{mg} / \mathrm{d})^{(18)}$ or ISSFAL $(>300 \mathrm{mg} / \mathrm{d})^{(19)}$. Statistical analyses were conducted with the SAS program for Windows v.9 (SAS Institute Inc., Cary, NC, USA). Differences between groups and associations were considered significant at $P \leq 0.05$ (bilateral).

\section{Results}

Demographic characteristics of the study respondents are presented in Table 2. Among the 993 adults who responded to the survey, forty-two had missing information on portion size, leaving 951 subjects for the estimation of intakes of marine food products and EPA + DHA. Of these, a total of 109 subjects $(11.5 \%)$ were non-consumers of marine food

Table 2 Characteristics of the study subjects ( $n$ 993)

\begin{tabular}{lr}
\hline Characteristics & $\%$ \\
\hline Female & $51 \cdot 9$ \\
Age (years) & $12 \cdot 2$ \\
$18-24$ & $39 \cdot 0$ \\
$25-44$ & $32 \cdot 4$ \\
$45-64$ & $16 \cdot 3$ \\
$\geq 65$ & \\
Family income in 2005 & $11 \cdot 7$ \\
$<\$ 19999$ & $26 \cdot 1$ \\
$\$ 20000$ to $\$ 39000$ & $36 \cdot 2$ \\
\$40 000 to \$99 000 & $10 \cdot 8$ \\
$\geq \$ 100000$ & $15 \cdot 3$ \\
Don't know/refuse to answer & \\
Education & $6 \cdot 1$ \\
Primary school (<7 years) & $36 \cdot 1$ \\
Secondary school (8-12 years) & $24 \cdot 4$ \\
College degree & $33 \cdot 4$ \\
University degree & \\
Occupation & $8 \cdot 5$ \\
Student & $3 \cdot 1$ \\
Unemployed & $7 \cdot 2$ \\
At home & $59 \cdot 3$ \\
Workers & $21 \cdot 9$ \\
Retired & \\
\hline
\end{tabular}




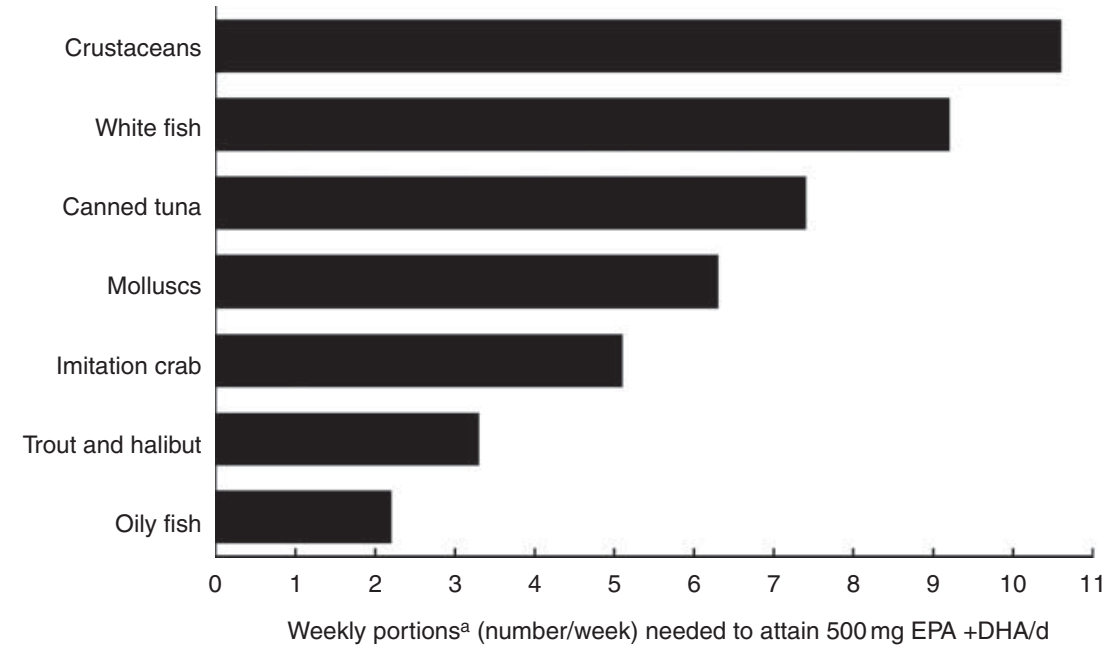

Fig. 1 Quantity of weekly portions* needed to attain the international recommendation of $500 \mathrm{mg}$ EPA + DHA/d. This daily EPA and DHA intake has been suggested by several health agencies worldwide (see Table 1) (*1 portion $=113 \mathrm{~g}(4 \mathrm{oz}) \mathrm{cooked}$; DHA, $22: 6 n-3$; EPA, $20: 5 n-3)$

products. Mean intakes $(\mathrm{g} / \mathrm{d})$ of oily fish, canned tuna, trout or halibut, white fish, molluscs, crustaceans and imitation crab were $12 \cdot 0$ (SD 16.4), $7 \cdot 3$ (SD 13.3), 3.6 (SD 8.3), $5 \cdot 6(\mathrm{sD} 10 \cdot 7), 1 \cdot 6(\mathrm{sD} 4 \cdot 0), 4 \cdot 9(\mathrm{sD} 7 \cdot 7)$ and $1 \cdot 7$ (SD $6 \cdot 4)$, respectively. Their EPA + DHA contributions $(\mathrm{mg} / \mathrm{d})$ were 179 (sD 244), 28 (sD 50), 34 (SD 77), 19 (sD 36), 8 (sD 20), 14 (SD 22) and 11 (SD 39), respectively. Total fish intake was $28.4 \mathrm{~g} / \mathrm{d}$ (SD 31.7) and contributed to an $\mathrm{EPA}+\mathrm{DHA}$ intake of $258 \mathrm{mg} / \mathrm{d}$ (SD 307). The mean intake of total marine food products was $36 \cdot 6 \mathrm{~g} / \mathrm{d}$ (SD 37.7). However, the median intakes of oily fish, total fish and marine food products were 7,19 and $28 \mathrm{~g} / \mathrm{d}$, respectively. Mean and median EPA + DHA intakes were estimated to be $291 \mathrm{mg} / \mathrm{d}$ (SD 328) and $207 \mathrm{mg} / \mathrm{d}$, respectively. The geometric mean of EPA + DHA intake was $217 \mathrm{mg} / \mathrm{d}$ (95\% CI 203, 232). EPA + DHA intakes were not statistically different between men and women $\left(t_{840}=1 \cdot 26\right.$, $P=0 \cdot 2097)$. However, the proportion of Quebecers who had an intake < $500 \mathrm{mg} \mathrm{EPA}+\mathrm{DHA} / \mathrm{d}$ was $85 \cdot 0 \%(95 \%$ CI $82 \cdot 7,87 \cdot 3)$, and was higher among males (88·8\%, 95\% CI $85 \cdot 9,91 \cdot 7)$ than females $(81 \cdot 5 \%, 95 \%$ CI $78 \cdot 0,84 \cdot 9)$ $\left(\chi^{2}=10 \cdot 0, \quad P=0 \cdot 0015\right)$. EPA + DHA intakes increased progressively with age $(P$ trend $=0 \cdot 0389)$, income $(P$ trend $=0.0020)$ and education $(P$ trend $=0.0441)($ data not presented). No statistical differences $(P>0 \cdot 05)$ were noted for geometric means of $\mathrm{EPA}+\mathrm{DHA}$ intake according to age or education groups. Among people with income $<\$ 20000$, the geometric mean of EPA + DHA intake was $151 \mathrm{mg} / \mathrm{d}(95 \%$ CI 121, 188) and was significantly lower $(P<0 \cdot 05)$ - by about $79 \mathrm{mg}-$ compared to other income classes.

Mean and median DHA intakes among women of childbearing age ( $n$ 128) were estimated to be $169 \mathrm{mg} / \mathrm{d}$ (SD 198) and $126 \mathrm{mg} / \mathrm{d}$, respectively. The geometric mean of DHA intake among these women ( $n$ 111) was $127 \mathrm{mg} / \mathrm{d}$ (95\% CI 104, 155). The proportions of women of childbearing age who had adequate DHA intake, as recommended by PeriLip ( $>200 \mathrm{mg} / \mathrm{d}$ DHA) and ISSFAL (>300 mg/d DHA), were $27 \cdot 7 \%$ (95\% CI 20.4, 35.1\%) and $15 \cdot 9 \%$ (95\% CI 9.9, 21.9\%), respectively.

The prevalence of fish oil capsule consumption ( $n$ 993) was $20 \cdot 7 \%$, with $13 \%$ taking $\geq 1$ capsule of fish oil/d. The prevalence of fish oil consumption $\left(\chi^{2}=0 \cdot 81, P=0 \cdot 369\right)$ and taking $\geq 1$ capsule of fish oil/d $\left(\chi^{2}=0 \cdot 40, P=0 \cdot 529\right)$ was not significantly different between men and women. Among women, the rate of $\geq 1$ capsule of fish oil/d was three times higher among older compared to younger women $(\geq 45$ years $=19 \cdot 1 \% v .<45$ years $=6 \cdot 2 \%, P<$ $0 \cdot 0001)$. However, this difference was not observed among males $(\geq 45$ years $=3.9 \% v .<45$ years $=9 \cdot 8 \%$, $P=0 \cdot 18$ ). Among participants aged $45-64$ years, the rate of $\geq 1$ capsule of fish oil/d was two times higher among women than men $(\mathrm{OR}=2 \cdot 0,95 \%$ CI $1 \cdot 05,3 \cdot 79)$. The weekly portions of each marine food category of the FFQ that are needed to attain international recommendations of $500 \mathrm{mg} / \mathrm{d}$ of EPA + DHA are shown in Fig. 1.

\section{Discussion}

In a representative sample of adults in the province of Quebec, we estimated mean and median EPA + DHA intakes to be $291 \mathrm{mg} / \mathrm{d}$ and $207 \mathrm{mg} / \mathrm{d}$, respectively. Several organisations have recognised the importance of consuming marine food products as well as $n$ - 3 LC PUFA to reduce the risks of CVD. In its recent revision of diet and lifestyle recommendations (2006), the American Heart Association urged the consumption of two fish meals per week (preferably fatty fish), which is equivalent to $430-570 \mathrm{mg}$ of EPA and DHA daily ${ }^{(34)}$. A review of the risks and benefits of fish consumption suggested that a modest intake of fish (1-2 fish meals/week), especially 
those rich in EPA and DHA, decreases the risk of CHD death by $36 \%{ }^{(40)}$. Analysis of fifteen randomised clinical trials indicates that $n-3$ LC PUFA reduce total mortality by $17 \%{ }^{(40)}$. A daily intake of $\approx 500 \mathrm{mg}$ of EPA and DHA has been chosen by many organisations as a target for CVD risk reduction ${ }^{(11)}$. Only $15 \cdot 0 \%$ of the Quebecers we surveyed had a self-proclaimed EPA + DHA intake $\geq 500 \mathrm{mg} / \mathrm{d}$. Moreover, the median intake of oily fish among these Quebecers was $49 \mathrm{~g} /$ week, which is equivalent to about one oily fish meal every 2 weeks. Compared to Western populations, the Japanese CHD death rate is very low and EPA + DHA intake is very high ${ }^{(41)}$. In our population, two fish meals/week is the target, whereas among the Japanese, the reference group (the lowest) is often comprised of those who eat 1-2 fish meals/week.

Among the women of childbearing age we surveyed, mean intake of DHA was $169 \mathrm{mg} / \mathrm{d}$ (SEM 17), a result agreeing with that of Innis and Elias who reported on fifty-five pregnant women in British Columbia ${ }^{(42)}$. They administered an FFQ between weeks 28 and 35 of pregnancy, and noted a mean DHA intake of $160 \mathrm{mg} / \mathrm{d}$ (SEM 20), with $16 \%$ of women they surveyed consuming $>300 \mathrm{mg}$ DHA/d. Similarly, we observed that $15.9 \%$ of women of childbearing age had a DHA intake $>300 \mathrm{mg} / \mathrm{d}$, and $27 \cdot 7 \%$ had a DHA intake $>200 \mathrm{mg} / \mathrm{d}$. Based on dietary intakes from a $3 \mathrm{~d}$ food record among twenty pregnant women from Ontario, Denomme et al. noted a mean DHA intake of $82 \mathrm{mg} / \mathrm{d}$ (SEM 33) ${ }^{(43)}$. The third trimester of pregnancy is a critical growth period that is highly susceptible to nutritional insults ${ }^{(16)}$. Clandinin et al. suggested that $80 \%$ of the DHA present in the human brain at birth accumulates during the third trimester ${ }^{(44)}$. DHA levels in the brain increase in parallel with rapid brain growth ${ }^{(45)}$, from the third trimester through the first years of life, and are closely linked to the presence of DHA in the infant's diet ${ }^{(15)}$. Combining our present results with two Canadian studies among pregnant women ${ }^{(42,43)}$, it seems clear that DHA intake among women of childbearing age or pregnant women in Canada is lower than what is recommended for pregnancy and lactation. These findings indicate a need for studies addressing the effects of low DHA intake on pregnancy outcomes and infant neurodevelopment in Canada.

To our knowledge, no other recently published studies have attempted to quantify fish consumption and dietary EPA + DHA intake among Quebecers. In our present work, mean intakes of total fish and total marine food products were $28.4 \mathrm{~g} / \mathrm{d}$ and $36.6 \mathrm{~g} / \mathrm{d}$, respectively. In the 1990 Santé-Québec survey among Quebecers, fish intake was determined by FFQ administered by a nutritionist during face-to-face interviews at home. The FFQ measured consumption during the month before the survey and included only two fish items: fish and fried fish. Each participant was asked to provide the usual frequency of consumption and the usual portion size. The participants' reported mean fish intake was $95 \mathrm{~g} /$ week during the month before the survey. The median intake of total fish consumed was $55 \mathrm{~g} /$ week. In the present study, median intake of oily fish and total fish was $49 \mathrm{~g} /$ week and $134 \mathrm{~g} /$ week, respectively. This divergence in results between the 1990 survey and our present survey can probably be explained by the proportion of non-consumers of fish in the 1990 Santé-Québec survey, which was $43.3 \%$ in 1990 but was only $11.5 \%$ in our survey. The different results may also be due to the use of two very different questionnaires. The FFQ in the present study evaluated the consumption of seven categories of marine food products, whereas the questionnaire in the 1990 SantéQuébec survey had only two questions, one of them on fried fish. EPA + DHA in RBC, a biomarker of marine $n-3$ fatty acid consumption, correlates very well with the risk of CHD death ${ }^{(46)}$ and with human myocardial $n-3$ concentration $^{(47)}$. EPA + DHA intake measured by our FFQ correlated reasonably well with EPA + DHA concentration in RBC (Spearman's $r=0 \cdot 42, P=0 \cdot 0005)^{(6)}$.

In North America, an increasing number of persons are turning to natural health products ${ }^{(48)}$. Indeed, according to 2000-2001 CCHS results, the proportion of Canadians who took fish oil was $9 \cdot 4 \%{ }^{(23)}$. In the present study, we noted that $20.7 \%$ of participants consumed fish oil capsules, with $13 \%$ ingesting $\geq 1$ capsule of fish oil/d. Among women, the rate of $\geq 1$ capsule of fish oil/d was three times higher among older compared to younger women, but this difference was not observed among males. In the CCHS, the prevalence of past $2 \mathrm{~d}$ natural health product use was 1.5-2 times higher in women between the ages of 36 and 75, than men of the same age group ${ }^{(23)}$. However, among participants aged 45-64 years, we noted that the rate of $\geq 1$ capsule of fish oil/d was two times higher among women than men. This confirms the fact that middle-aged women are important consumers of natural health products ${ }^{(23)}$. However, we did not ask about the format or $n-3$ concentration of fish oil taken and we were, therefore, unable to estimate EPA and DHA intake from fish oil. Since $13 \%$ of the Quebecers we surveyed take more than 1 fish oil capsule/d, the EPA + DHA intake among some Quebecers is probably higher than the level estimated by only the FFQ. In addition, the dietary EPA and DHA intakes of Quebecers might be higher than we estimated because a low level of those $n-3$ fatty acids might be provided by chicken and regular egg consumption (an additional contribution of $\approx 30 \mathrm{mg}$ of $\mathrm{EPA}+\mathrm{DHA} / \mathrm{d})^{(39)}$. Moreover, EPA + DHA intake may be even higher if Quebecers consume food products, such as eggs, yoghurts, milk, cheese and beverages, fortified with these $n-3$ fatty acids.

Our study has a number of limitations. Data collection by telephone survey is relatively quick and inexpensive, but it has the problem of growing coverage and falling response rates. Indeed, the major biases with telephone surveys are observational errors (or sampling errors), such as non-coverage bias, non-response bias (non-participation) 
and sampling bias ${ }^{(49)}$. Because of the trend away from fixed landlines to cellular phones, the non-coverage bias is becoming a major problem in telephone survey research. Even if ownership of cellular phones is high among Quebecers (46\%), most of these adults also have landline telephone service (Léger Marketing, personal communication). Indeed, 98-99\% of Quebecers have a fixed landline phone, and only $1 \%$ has no service at all. It is generally accepted that the response rate to telephone surveys is decreasing ${ }^{(50)}$. Reports have indicated that for response rates in the $40-70 \%$ range, non-response bias does not appear to significantly affect survey estimates $^{(51,52)}$. A comparison of non-responses in surveys revealed that face-to-face situations had the highest completion rate, telephone surveys, the next highest, and mail surveys, the lowest ${ }^{(53)}$. Our response rate was $56.9 \%$. Moreover, our results were weighted according to the latest Statistics Canada data to make the sample representative of the adult Quebec population. Taken together, these potential sampling errors are unlikely to have seriously influenced our findings.

Other limitations could be attributed to the fact that our FFQ has been validated in face-to-face interviews among middle-aged women ${ }^{(6)}$. However, conversion of $\alpha$-LNA to EPA or DHA has been suggested to be higher among young women due to oestrogen ${ }^{(54)}$. Nevertheless, if the $\alpha$-LNA conversion rate is likely higher among women compared to men, it indicates that the relationship between $\mathrm{EPA}+$ DHA intakes and RBC EPA + DHA concentrations might be at least equal, or superior, to that in men. However, data from our validation study were selfreported. Therefore, the results might be different since distinct modes of administration of the FFQ were used. Another limitation that affects every FFQ or any estimated nutrient intake tool is the utilisation of nutrient databases that might not adequately reflect temporal changes in food composition ${ }^{(55)}$. Moreover, dietary EPA and DHA may vary considerably in the same fish species. We previously noted, that EPA + DHA in skinless fillets (100 g raw) of farmed Atlantic salmon and rainbow trout ranged, respectively, between $414-1460 \mathrm{mg}$ and $263-1334 \mathrm{mg}^{(56)}$. In addition, intakes of EPA and DHA can be very different if consumers eat only skinless fillets or subcutaneous fat.

If the recommendation to consume two fish meals/ week is to become the norm in the Quebec population, modifications of the food environment and public health strategies are warranted. To reach the international recommendation of $500 \mathrm{mg}$ of $\mathrm{EPA}+\mathrm{DHA} / \mathrm{d}$, two meals (113 g or $4 \mathrm{oz}$ ) per week of oily fish are required, whereas nine meals of white fish would be needed (Fig. 1). Consumption of fatty fish, such as salmon, herring, mackerel or sardines, is the cheapest and easiest way to increase $\mathrm{EPA}+\mathrm{DHA}$ intake. However, a large proportion of the population is unable or unwilling to consume EPA + DHA from fish alone. In fact, only one-third of the participants reported an oily fish intake of $\geq 1 \mathrm{meal} /$ week. Alternative strategies would be the intake of fish oil capsules or increased intake of foods enriched with $n$ - 3 LC PUFA. Even if fish oil capsules are associated with health benefits $^{(4,9,10)}$ and with reduced health costs from secondary CHD prevention ${ }^{(57,58)}$, fish and seafood are still preferred because they contain nutrients other than $n$ - 3 fatty acids and, thus, represent an integral part of a healthy lifestyle.

In conclusion, the estimated intake of marine food products and EPA + DHA among adult Quebecers is much lower than international recommendations. Since $n$-3 LC PUFA confer health benefits and may reduce health costs, strategies to increase their consumption should be implemented to improve public health in Quebec.

\section{Acknowledgements}

The present study was supported in part by grants from the Lucie and André Chagnon Chair of Laval University, the Department of Medicine, Sherbrooke University (post-doctoral fellowship to M.P.), Canada Research Chairs and the Natural Sciences and Engineering Research Council (S.C.C.). None of the authors have reported any financial or personal conflict of interest to the present manuscript. As the principal investigator, M.L. had full access to the study data, and takes responsibility for the integrity of the data and accuracy of the data analysis. The contributions of each author in this work are as follows: study concept and design - M.L., G.A. and S.D.; development of the FFQ and analysis of the data - M.L.; data interpretation - M.L., G.A., M.P., S.C.C., E.D. and S.D.; drafting the manuscript - M.L., M.P. and S.C.C.; critical revision of the manuscript - M.L., G.A., M.P., S.C.C., E.D. and S.D. The authors also express their gratitude to all participants in this survey.

\section{References}

1. Simopoulos AP (2006) Evolutionary aspects of diet, the omega-6/omega-3 ratio and genetic variation: nutritional implications for chronic diseases. Biomed Pharmacother 60, 502-507.

2. Harris WS (2006) The omega-6/omega-3 ratio and cardiovascular disease risk: uses and abuses. Curr Atheroscler Rep 8, 453-459.

3. Kris-Etherton PM, Harris WS \& Appel LJ (2002) AHA Scientific Statement. Fish consumption, fish oil, omega-3 fatty acids, and cardiovascular disease. Circulation 106, $2747-2757$.

4. Calder PC (2006) n-3 polyunsaturated fatty acids, inflammation, and inflammatory diseases. Am J Clin Nutr 83, 6 Suppl., 1505S-1519S.

5. Plourde M \& Cunnane S (2007) Extremely limited synthesis of long chain polyunsaturates in adults: implications for their dietary essentiality and use as supplements. Appl Physiol Nutr Metab 32, 619-634.

6. Lucas M, Asselin G, Mérette C, Poulin MJ \& Dodin S (2008) Validation of an FFQ for evaluation of EPA and DHA intake. Public Health Nutr (Epublication ahead of print version). 
7. Anderson CA \& Appel LJ (2006) Dietary modification and CVD prevention: a matter of fat. JAMA 295, 693-695.

8. Mosca L, Appel LJ, Benjamin EJ et al. (2004) Evidencebased guidelines for cardiovascular disease prevention in women. American Heart Association scientific statement. Arterioscler Thromb Vasc Biol 24, e29-e50.

9. Wang C, Harris WS, Chung M, Lichtenstein AH, Balk EM, Kupelnick B, Jordan HS \& Lau J (2006) $n$-3 fatty acids from fish or fish-oil supplements, but not alpha-linolenic acid, benefit cardiovascular disease outcomes in primaryand secondary-prevention studies: a systematic review. Am J Clin Nutr 84, 5-17.

10. Freeman MP, Hibbeln JR, Wisner KL et al. (2006) Omega-3 fatty acids: evidence basis for treatment and future research in psychiatry. J Clin Psychiatry 67, 1954-1967.

11. Gebauer SK, Psota TL, Harris WS \& Kris-Etherton PM (2006) $n-3$ fatty acid dietary recommendations and food sources to achieve essentiality and cardiovascular benefits. Am J Clin Nutr 83, 6 Suppl., 1526s-1535s.

12. Makrides M (2008) Outcomes for mothers and their babies: do $n$-3 long-chain polyunsaturated fatty acids and seafoods make a difference? J Am Diet Assoc 108, 1622-1626.

13. Crawford MA (2000) Placental delivery of arachidonic and docosahexaenoic acids: implications for the lipid nutrition of preterm infants. Am J Clin Nutr 71, 1 Suppl., 275s-284s.

14. Innis SM (2003) Perinatal biochemistry and physiology of long-chain polyunsaturated fatty acids. J Pediatr $\mathbf{1 4 3}$, 4 Suppl., 1s-8s.

15. Cunnane SC, Francescutti V, Brenna JT \& Crawford MA (2000) Breast-fed infants achieve a higher rate of brain and whole body docosahexaenoate accumulation than formulafed infants not consuming dietary docosahexaenoate. Lipids 35, 105-111.

16. Carlson SE (2009) Docosahexaenoic acid supplementation in pregnancy and lactation. Am J Clin Nutr 89, 678s-684s.

17. Francois CA, Connor SL, Bolewicz LC \& Connor WE (2003) Supplementing lactating women with flaxseed oil does not increase docosahexaenoic acid in their milk. Am J Clin Nutr 77, 226-233.

18. Koletzko B, Cetin I \& Thomas Brenna J (2007) Dietary fat intakes for pregnant and lactating women. Br J Nutr $\mathbf{9 8}$, 873-877.

19. Simopoulos AP, Leaf A \& Salem N Jr (2000) Workshop statement on the essentiality of and recommended dietary intakes for omega- 6 and omega-3 fatty acids. Prostaglandins Leukot Essent Fatty Acids 63, 119-121.

20. Santé-Québec (1995) Les Québécoises et Québécois mangent-ils mieux? Rapport de l'enquête québécoise sur la nutrition, 1990 (Report of the Nutrition Survey among Quebecers, 1990). Montréal: Ministère de la santé et des services sociaux, Gouvernement du Québec.

21. Dewailly E, Blanchet C, Gingras S, Lemieux S \& Holub BJ (2003) Fish consumption and blood lipids in three ethnic groups of Quebec (Canada). Lipids 38, 359-365.

22. Kris-Etherton P, Taylor DS \& Yu-Poth S (2000) Polyunsaturated fatty acids in the food chain in the United States. Am J Clin Nutr 71, Suppl. 1, 179s-188s.

23. Singh SR \& Levine MA (2006) Natural health product use in Canada: analysis of the National Population Health Survey. Can J Clin Pharmacol 13, e240-e250.

24. Cardiovascular Review Group, Committee on Medical Aspects of Food Policy (1994) Nutritional Aspects of Cardiovascular Disease. Report on Health and Social Subjects. London, UK: Department of Health.

25. Food and Nutrition Board (FNB) of the Institute of Medicine of the National Academies (2002) Dietary fats: total fat and fatty acids. In Dietary Reference Intakes for Energy, Carbohydrates, Fiber, Fats, Fatty Acids, Cholesterol, Protein and Amino Acids (Macronutrients), pp. 422-541.
Washington, DC: The National Academies Press; available at http://newton.nap.edu/books/0309085373/html/422.html

26. Eurodiet (2000) Nutrition \& diet for healthy lifestyles in Europe. http://eurodiet.med.uoc.gr/ (accessed September 2006).

27. Health Council of the Netherlands (2001) Dietary Reference Intakes: Energy, Proteins, Fats, and Digestible Carbohydrates. Report 19. The Hague: Health Council of the Netherlands.

28. Martin A (2001) Apports nutritionnels conseillés pour la population française, 3rd ed. Paris: Lavoisier.

29. National Health and Medical Research Council (2005) Nutrient Reference Values for Australia and New Zealand Including Recommended Dietary Intakes. Canberra: Australian Government, Department of Health and Ageing, NHMRC, Ministry of Health; available at http://www. nhmrc.gov.au/publications/synopses/n35syn.htm

30. World Health Organization (2003) Joint WHO/FAO Expert Consultation on Diet, Nutrition and the Prevention of Chronic Diseases. WHO Technical Report Series no. 916. Geneva: WHO; available at http://www.who.int/nut/ documents/trs_916.pdf

31. UK Scientific Advisory Committee on Nutrition (2004) Advice on fish consumption: benefits \& risks. http:// www.sacn.gov.uk/reports/ (accessed September 2006).

32. Cunnane S, Drevon CA, Harris B, Sinclair A\& Spector A (2004) Recommendations for intake of polyunsaturated fatty acids in healthy adults. International Society for Study of Fatty Acids and Lipids (ISSFAL) Subcommittee. http:// www.issfal.org.uk/pufa\%20intakes.htm (accessed September 2004).

33. American Dietetic Association (2007) Position of the American Dietetic Association and Dietitians of Canada: dietary fatty acids. J Am Diet Assoc 107, 1599-1611.

34. American Heart Association Nutrition Committee, Lichtenstein AH, Appel LJ, Brands M et al. (2006) Diet and lifestyle recommendations revision 2006: a scientific statement from the American Heart Association Nutrition Committee. Circulation 114, 82-96.

35. Simopoulos AP, Leaf A \& Salem N Jr (1999) Essentiality of and recommended dietary intakes for omega- 6 and omega3 fatty acids. Ann Nutr Metab 43, 127-130.

36. Simopoulos AP (1989) Summary of the NATO advanced research workshop on dietary omega 3 and omega 6 fatty acids: biological effects and nutritional essentiality. $J$ Nutr 119, 521-528.

37. British Nutrition Foundation (1992) Unsaturated Fatty Acids. Nutritional and Physiological Significance. The Report of the British Nutrition Foundation's Task Force. London: British Nutrition Foundation.

38. Van de Werf F, Ardissino D, Betriu A et al. (2003) Management of acute myocardial infarction in patients presenting with ST-segment elevation. The Task Force on the management of acute myocardial infarction of the European Society of Cardiology. Eur Heart J 24, 28-66.

39. Health Canada (2005) Canadian Nutrient File. Health Canada. http://www.hc-sc.gc.ca/fn-an/nutrition/fiche-nutridata/index_e.html (accessed October 2006).

40. Mozaffarian D \& Rimm EB (2006) Fish intake, contaminants, and human health: evaluating the risks and the benefits. JAMA 296, 1885-1899.

41. Iso H, Kobayashi M, Ishihara J, Sasaki S, Okada K, Kita Y, Kokubo Y \& Tsugane S (2006) Intake of fish and $n$-3 fatty acids and risk of coronary heart disease among Japanese. The Japan Public Health Center-Based (JPHC) Study Cohort I. Circulation 113, 195-202.

42. Innis SM \& Elias SL (2003) Intakes of essential $n-6$ and $n-3$ polyunsaturated fatty acids among pregnant Canadian women. Am J Clin Nutr 77, 473-478.

43. Denomme J, Stark KD \& Holub BJ (2005) Directly quantitated dietary ( $n-3)$ fatty acid intakes of pregnant 
Canadian women are lower than current dietary recommendations. J Nutr 135, 206-211.

44. Clandinin MT, Chappell JE, Leong S, Heim T, Swyer PR \& Chance GW (1980) Intrauterine fatty acid accretion rates in human brain: implications for fatty acid requirements. Early Hum Dev 4, 121-129.

45. Martinez M (1992) Tissue levels of polyunsaturated fatty acids during early human development. J Pediatr 120, s129-s138.

46. Harris WS \& Von Schacky C (2004) The Omega-3 Index: a new risk factor for death from coronary heart disease? Prev Med 39, 212-220.

47. Harris WS, Sands SA, Windsor SL, Ali HA, Stevens TL, Magalski A, Porter CB \& Borkon AM (2004) Omega-3 fatty acids in cardiac biopsies from heart transplantation patients. Correlation with erythrocytes and response to supplementation. Circulation 110, 1645-1649.

48. Kessler RC, Davis RB, Foster DF, Van Rompay MI, Walters EE, Wilkey SA, Kaptchuk TJ \& Eisenberg DM (2001) Long-term trends in the use of complementary and alternative medical therapies in the United States. Ann Intern Med 135, 262-268.

49. American Statistical Association (2004) What is a survey? ASA Series [F Scheuren, editor]. http://www.whatisasurvey. info/ (accessed November 2006).

50. Johnson TP, Holbrook AL, Ik Cho Y \& Bossarte RM (2006) Nonresponse error in injury-risk surveys. Am J Prev Med 31, 427-436.
51. Keeter S, Miller C, Kohut A, Groves RM \& Presser S (2000) Consequences of reducing nonresponse in a national telephone survey. Public Opin Q 64, 125-148.

52. Curtin R, Presser S \& Singer E (2000) The effects of response rate changes on the index of consumer sentiment. Public Opin Q 64, 413-428.

53. Hox JP \& De Leeuw ED (1994) A comparison of nonresponse in mail, telephone, and face-to-face surveys: applying multilevel modeling to meta-analysis. Qual Quant 28, 329-344.

54. Burdge G (2004) Alpha-linolenic acid metabolism in men and women: nutritional and biological implications. Curr Opin Clin Nutr Metab Care 7, 137-144.

55. Cantwell MM (2000) Assessment of individual fatty acid intake. Proc Nutr Soc 59, 187-191.

56. Blanchet $C$, Lucas $M$, Julien $P$, Morin $R$, Gingras S \& Dewailly E (2005) Fatty acid composition of wild and farmed Atlantic salmon (Salmo salar) and rainbow trout (Oncorbynchus mykiss). Lipids 40, 529-531.

57. Schmier JK, Rachman NJ \& Halpern MT (2006) The costeffectiveness of omega-3 supplements for prevention of secondary coronary events. Manag Care 15, 43-50.

58. Lamotte M, Annemans L, Kawalec P \& Zoellner Y (2006) A multi-country health economic evaluation of highly concentrated N-3 polyunsaturated fatty acids in secondary prevention after myocardial infarction. Pharmacoeconomics 24, 783-795. 